\title{
A Sudden Loss of Rights
}

\begin{abstract}
This chapter presents the problem of legal uncertainty afflicting second country nationals in the UK and British citizens turning from expats to post-European third country nationals. First we look at the case of European citizens living in the UK and then we look at British citizens residing in other parts of the Union. Real-world cases are presented. The narration of the cases enables the reader to appreciate the multitude of effects and the layers of issues involved. They also allow pointing out how dramatic a change like Brexit may be in the lives of those involved. The reader who feels comfortable in mastering the legal complexities affecting those who have relied on free movement in making their life choices can move on to the next chapter.
\end{abstract}

Keywords European citizenship - Brexit - Second country national . Third country national . United Kingdom . Freedom of movement . Right of residence $\cdot$ EU law $\cdot$ Migration law

There is a lot of uncertainty about the future situation of second country nationals in the UK and of British nationals in other parts of the EU. There are political reasons for fearing that second country nationals after Brexit may face a 'dramatic loss of rights' (Kochenov 2016a). To some, this is 'one of the most serious risks of a UK withdrawal from the EU' (Douglas-Scott 2016). As evidenced by Jo Shaw, 'UK have long been

(C) The Author(s) 2017

P. Mindus, European Citizenship after Brexit, Palgrave Studies in European Union Politics, DOI 10.1007/978-3-319-51774-2_3 
uncomfortable navigating the space between the political truth of popular hostility to immigration and the legal commitments of the UK to the EU Treaties. On that account, EU citizens exercising free movement rights are simply "lucky immigrants"' (Shaw 2016). ${ }^{1}$ It has been submitted that "to abolish many of these rights en bloc, with minimal or no parliamentary scrutiny, undermines fundamental rights, but is also undemocratic and detrimental to the parliamentary sovereignty' (Douglas-Scott 2015).

In the event of a non-negotiated exit, Union citizens would lose their right to live in the UK based on the Treaties and EEA nationals in the UK will no longer benefit from the rights contained in the Citizens Directive 2004/38/EC, implemented into British domestic law via the Immigration (EEA) Regulations from 2006. The UK could apply its national immigration laws to all EEA citizens, that would require (merely) repealing s 7(1) of the Immigration Act 1988, which provides that leave to enter or remain in the UK under the Immigration Act 1971 is not required by a person who is entitled to enter the UK by virtue of EU rights.

Any arrangements that allow EU citizens to continue to live and work in the UK have to be negotiated, just as UK nationals in member states who will lose Union citizenship after EU law ceases to include them in its 'personal sphere of validity' (Kelsen 1945). Also prospective EU migrants, that is, those who wish to migrate to the UK after Brexit would be affected, but I shall leave this aside. ${ }^{2}$ They would be subjected to the full force of British immigration law in the event of an agreement-less exit, but in absence of 'acquired rights.' An intriguing case would be family members wishing to join second country nationals in the UK: Can they claim rights if the family relationship is prior to Brexit? Most certainly, they would be excluded from the protection offered within the ambit of Union law: The ECJ has qualified the 'genuine substance' doctrine of Ruiz Zambrano pointing out that the mere desire to keep a family together does not constitute ground for accommodating claims by third country nationals. ${ }^{3}$

Naturally, the so-called vested rights for EU citizens in the UK and for UK citizens in the EU cover a much broader subject matter than freedom of movement, including, for example, social policy, non-discrimination law and fundamental rights. Here we will deal foremost with free movement since the Brexit debate centred on migration. Even narrowing down the topic in this way the numerous difficulties that emerge promise an increased workload ahead. 
Modifications in legal position will affect approx. 2.9 million nonBritish EU citizens in the UK and approx. 690,000 UK citizens currently living in EU member states. This assertion stands in stark contrast to often repeated claims: The media has reported that second country nationals in the UK would amount to $3-3.3$ million and that UK citizens residing in other member states would amount to 1.2-1.3 million. A few sources refer to the unofficial data of the Migration Observatory based on its analysis of Labour Force Survey. ${ }^{4}$ But most sources take these figures from the UN. ${ }^{5}$ This data, however, refers to persons residing in a country or geographical area by their country of birth. Legal positions are not held in virtue of 'place of birth' but citizenship: Ius soli at birth is not the sole mode of acquisition of nationality. Ius sanguinis allows for naturalisation abroad and acquisition of nationality by birth for persons born abroad. EU citizenship depends on the nationality of a member state, pursuant to Art. 20(1) TFEU. Eurostat records nationality, making it a preferable source of data. 'The use of UN data in this context may result in discrepancies and misrepresentation of the impact of Brexit of UK and EU nationals' (Carrera et al. 2016). Not even Eurostat data is to be relied upon entirely: National statistics may include dual nationals holding UK and the reporting country's nationality. Eurostat data is nonetheless preferable to UN data. Based on Eurostat data combined with the UK Office for National Statistics (ONS), there were around 2.9 million second country nationals residing in the UK on 1 January 2015. Polish, Irish and Romanian nationals are top three of second country nationalities present in the UK. There were also around 690,000 British citizens residing in other EU member states. ${ }^{6}$ The majority of these UK citizens reside in Spain, but a significant number are living in Ireland, Germany, the Netherlands, Italy, Belgium and Sweden.

Behind the numbers, there are individuals who, according to their specific circumstances, will be affected by Brexit in quite different ways. Let us start by looking more closely, in the next section, at the situation for second country nationals living in the UK and then, in Section 3.2, at the situation of British nationals residing in other parts of the Union. The narration of the real-world cases presented below aim to enable appreciation of the multitude of effects and the layers of issues involved. They also allow pointing out how dramatic a change like Brexit may be in the lives of those involved. The reader who feels comfortable in mastering the legal complexities affecting those who have relied on free movement in making their life choices can move on to the next chapter. 


\subsection{The Home Office's New Workload}

Second country nationals in the UK will not lose their status as Union citizens; they recover full rights on return to the 'territory of the Union' (Azoulai 2014) and keep non-territorial rights associated with European citizenship, such as consular protection. It is not evident either that EU citizens resident in the UK will automatically be subjected to restricted political rights because of Brexit. Twenty-two member states allow their citizens to vote for the European Parliament when they reside in a non-EU state. ${ }^{7}$ Additionally:

there are sound reasons for the EU institutions to pressure the remaining five to change their policy, especially in light of the Court of Justice's Zambrano ratio that Member States should not hinder 'the genuine enjoyment of the substance of rights conferred by virtue of their status as citizens of the Union'. Moreover, it is not implausible that the Court of Justice's Delvigne will prompt a legal challenge to disenfranchisement of Union citizens residing in non-EU Member States (Ziegler 2016).

Given that Article 20 TFEU does not make any reference to residence, the scope of personal validity of European citizenship cannot be limited with reference to residence, as shown in Eman \& Sevinger. ${ }^{8}$ For European migrants in the UK - simply 'aliens' after Brexit - the withdrawal agreement is key to understanding their future situation. According to an oftenmade statement - to be tested - those with permanent residence would be given indefinite leave to remain. ${ }^{9}$ But a number of hard cases are susceptible of arising. In particular, there is a timing problem for defining 'acquired rights': Will the negotiated solution take into consideration rights in the process of being acquired such as legal positions of those who are working towards a permanent right of residence? Or will there be a cut off date for determining acquired rights? Will that date be Brexit? Will all those who had not matured the permanent right to reside by Brexit-day have their right to stay invalidated ex tunc?

Consider, for example, Charlotte, the 15-year-old daughter of French citizens living in London: Will she have a claim to equal treatment in respect of university fees as she will turn 18 after Brexit date? And will a degree taken in the UK even be recognised in EU27? ${ }^{10}$ Or take Belgian Olivier, a self-employed psychologist in Bristol, who gets married to his girlfriend from Singapore: Will he be able to bring his spouse to the UK or 
will he need to prove, in accordance with the more restrictive British policy, that he earns $£ 18,600 \mathrm{pa}$, which he, as almost half of the UK population, does not? The Greek Stephanos worked a couple of years on a part-time low paying teaching job before obtaining a PhD grant. Students also need to have a 'comprehensive sickness insurance' but he is among the 1/1000 inhabitants in Europe with a diagnosis of multiple scleroses, so no private insurer will insure him for 'previously existing conditions.' Will he lose the right to reside that he was in the process of acquiring or can he retain his previous worker condition? This also puzzles Leila from Luxembourg who did have a job, but that she was forced to leave while pregnant. As primary carer of her two-year-old son David, she has not yet found employment. Will she be able to stay? Sean is sarcastic and thinks the very existence of multiple citizenship undermines the point of Brexit, if the point was - as Cameron has stated - an issue about immigration. In a pub in Belfast he argues that dual citizenship may be the answer for many. That European citizens are naturalising in the UK (or at least seeking permanent residence documentation as the first step to naturalisation) would be an indication of how to stay as a UK citizen while keeping EU citizenship. This prospect seems less convincing to Robert from Vienna who fears that the ban on multiple nationality enforced in certain member states, makes it rather implausible.

Furthermore, consider the Italian Irene who has been part-time student and part-time waitress in the City for eight years and is married to Andrea, from Brazil, who got in on a visa as a family member of a European citizen in 2014 and still has three years left on visa when Brexit occurs: Irene finds out that she can naturalise but if she does, Andrea might lose the ability to exercise treaty rights in the UK. ${ }^{11}$ Irene figures that the UK will still be bound by the European Convention of Human Rights (ECHR): Its Article 8 on 'family life' is widely drawn and the case-law - she is told by a friend who studied law - has proven that Art. 8 would cover Andrea's 'legitimate expectation to live in the country.' But if she is wrong, Andrea might need to leave for Brazil. Should Irene apply for naturalisation?

Now, consider self-sufficient Ulrike from Germany, who has been married to Peter, and living in Sussex for almost two decades. She now discovers that, for the Home Office, her ability to use the NHS - which she has regularly used most notably when giving birth to their children does not count as 'comprehensive sickness insurance' so therefore she has never built up a right of residence. ${ }^{12}$ She was just physically present in the UK, they tell her. But she knows she could get a European health 
insurance card from her home country and even get it backdated. There is a reciprocal healthcare arrangement with Germany. The Home Office, though, requires her to sign a declaration if she wants to use for this option: She must declare that she has no intention of staying permanently in the UK: What is she going to tell her husband?

More worried, however, is Francisca from Lisbon, who came to England a decade ago, at the age of eight with her abusive father who found a job in a manufacturing in Herefordshire. Her younger brother Santiago, aged 17, who always seems to get into trouble, has been sentenced to deportation after committing a crime in the UK punishable with imprisonment for 12 months. Prior to Brexit, European citizens could be removed only on serious grounds of public policy and public security, pursuant to Art. 28 of the 2004 Citizens Directive. But after Brexit, the law that applies might be Section 3(5) IA 1971 of the domestic legal order that commands at the second comma (b) to deport a non-UK citizen if 'another person to whose family he belongs is or has been ordered to be deported.' Even though pregnant and a long-term resident of the UK, Francisca fears she might be expelled since Brexit Britain would not need to comply with the European law principle of proportionality that has hitherto mitigated removal practices. Post-Brexit UK could thus practice removals without paying due attention to age, health status, family or economic situation, social and cultural integration into the host society. Notable in this perspective are also the key provisions for automatic deportation of non EEA-nationals under UK Border Act 2007. Is her fear misplaced? Can the UK pursue an energetic expulsion policy?

Legal uncertainty is destined to increase. It may be relevant to address the hard cases to come in a future Brexit withdrawal treaty and/or treaties over the future relations with the UK so as to curb future litigation and limit the number of administrative errors that are likely to rise, given 'the manifest inability of the Home Office and the various associated agencies even to deal effectively with their existing workload without putting several million more people under immigration control' (Shaw 2016).

\subsection{From Expat to Post-European}

No matter the shape, Brexit would impact significantly on the citizenship of the Union, in a particularly unhappy way for British nationals living in the Union. The citizenry is predicted to shrink in size, change in composition and some parts of it will be left in potentially vulnerable positions. 
The Union citizenry has of course always been dynamic, not merely due to inherent demographical factors and enlargement but also due to modifications of member states' nationality laws. To give examples pertinent to the $\mathrm{UK}$, there was an artificial increase of the number of British nationals when the status was extended to include the inhabitants of the Falklands in 1983, the population of Hong Kong in 1997 and to some 200,000 citizens of British overseas territories in 2002 (De Groot 2004, p. 7). ${ }^{13}$ Brexit, however, constitutes a novelty: For the first time we are witnessing an automatic and collective lapse of status for Union citizens of exclusively British nationality.

Brexit is expected to cause an automatic en masse loss of European citizenship for individuals, residing on both sides of the border of the UK. Particularly vulnerable are those who have relied on free movement in making their life choices. Unsurprisingly, anecdotal evidence from Belgium has suggested large numbers of British residents there making applications for citizenship. The media has reported that across 18 European member states, some 2,800 Britons applied for citizenship in the first eight months of 2016 , estimated to correspond to a more than $250 \%$ increase on numbers recorded in 2015 . $^{14}$

A non-negotiated Brexit would transform all Union citizens of exclusively British nationality in third country nationals (TCNs): They would lose rights associated with the status, including freedom of movement and residence, ${ }^{15}$ voting rights in municipal ${ }^{16}$ and European Parliament elections, consular protection by another EU country, right to adhere to European citizens' initiatives (Art. 11 TEU \& Art. 24 TFEU) as well as the principle that holds EU citizenship rights together, that is, the right to non-discrimination on grounds of nationality (Art. 18 TFEU) - viewed by some as the groundbreaking thrust of Union citizenship (Kostakopoulou 2008; Eleftheriadis 2012) and by others as a normatively suspect way of clinging to market citizenship (Somek 2011). Along with the status goes also jurisprudentially developed protections, such as the right to export benefits and entitlements tied to nationality in a host member state $e^{17}$ and the right not to be burdened, or discriminated for having exercised the freedom to move. ${ }^{18}$

Not all British citizens would lose rights associated with European citizenship whose personal scope is over-inclusive in respect of having the nationality in a member state. British citizens in the Union would retain these rights also as third country nationals. These rights are often called 'citizens' rights' but they are really recognised to all residents: Such 
as the right to petition Parliament and the Ombudsman (Article 24) from the Maastricht Treaty, the right, introduced with the Nice Charter in 2000, to access documents from European Parliament, Council and Commission (Art. 42) and the right to good administration (Art. 41). Neither would UK nationals lose the right, introduced with the Treaty of Amsterdam in 1997, to address the EU in any official language and to receive a reply in that same language (Art. 24), since other member states use English as official language.

Moreover, the EU has partially harmonised immigration laws: Article 77 TFEU provides that the Union is competent to adopt rules relating to the absence of internal border controls, the management of external borders and short stay visa policy; Article 79 TFEU provides that the Union may adopt rules relating to the conditions of entry and residence, the definition of the rights of third country nationals residing legally, illegal immigration and unauthorised residence and combating human trafficking. Harmonisation in these areas means that the laws applicable to British citizens in the Union would be a mixture of common European standards and the residual domestic immigration laws of each of the member states. Basically, it entails increased scrutiny of British nationals at EU borders.

The Union could impose visa requirements, including for short-term trips and holidays, since the UK is not a party to the earlier treaty on Regulations governing the Movement of Persons between Member States of the Council of Europe from 1957 that abolished visa requirements between European states. Steve Peers, for one, argues that visas might be imposed on all EU travel after a Brexit (Peers 2016b). He has also argued that:

the EU would be free to impose visa requirements on UK citizens in the event of withdrawal. While the EU tends not to impose visa requirements on wealthy countries, it does expect such countries (such as the USA and Canada) in return to exempt all EU citizens from a visa. So if the UK wished to impose visas (for instance) on Romanians and Bulgarians, it would face pressure from the EU to waive such requirements - or face the imposition of a visa requirement for UK citizens (Peers 2016a).

Those who sought to reside for longer periods in the Union would be subject to the EU rules on immigration including quotas and EUpreference rules on labour migration. 'The transition from freedom to 
restriction will be painful for many. There will be many cases that fall through the cracks, and vast amounts of insecurity and pain' (Shaw 2016).

Consider, for example, Timothy who is a ballet dancer in Paris. Would he be granted a Blue Card to continue the profession or would he be considered self-employed subjected to the intricate French regulations? How about his flatmate Christopher who works as an assistant on a project at a local university: Does he now fall within the remit of the European Directive on third country national researchers? ${ }^{19}$ What happens to Margaret, who is one of the 106,610 claiming UK pension in Spain? ${ }^{20}$ She sold her house in Cambridgeshire and retired on the Costa Brava. Will the European rules that guarantee the upgrading of her British pension no longer apply? Sally, an unpaid trainee at a multinational in Amsterdam, is offered work in a subsidiary in Slovakia: Can she accept and bring her husband with her? Would she discover she needed to fall within the remit of the intra-corporate transfers? Or within the remit of the European Directive on Students? ${ }^{21}$ How about Ryan who catwalks for the autumn collection in Milan: Would he have some limited equality rights under the single permit directive (2011/98/EU) or would he be considered a seasonal worker, in which case his residence would be subject to a strict time limit? ${ }^{22}$ Bryce, who teaches English in Krakow, will have a tough time bringing over his mother Allie who needs care: She would count as third country national family member and member states have stricter domestic regulations on family reunion than the regime applicable to Union citizens. Cillian, originally from Belfast, has been living in Madrid for over a decade working as a software developer. Frustrated by not having his say in the referendum, he considers naturalising to fool his country's intention of stripping him of his rights as European citizen. Would he be able to pass the language proficiency test (DELE, Diplomas de Español como Lengua Extranjera) and another one on his knowledge of Spain (CCSE, La prueba de conocimientos constitucionales y socioculturales de España) that Spain imposes since October 2015? Would he need to renounce his original nationality to naturalise in Spain? Kylie, from Gibraltar, runs a bed and breakfast in Barcelona since 2010: Will she be required to apply for the European status of long-term residency for third country nationals or can she keep the more advantageous permanent residency? Dexter is part of an avant-garde theatre group in Amsterdam but he lacks any serious command of Dutch: Can he naturalise or will he be hindered by the 'integration test' the Netherlands imposes since 2007? Abigail, who is a part-time tourist guide in Stockholm, is anxious about her studies in biology: Would they let her continue working? Will she now need to pay the 15,000 -euro tuition fees for non-EU nationals? 
Annabel came to Rome as a student. She has a relationship with an older, married man and does not want to go home. Her American cousin overstayed her visa in Australia. Can she just stay put? Maybe her lover will file for divorce? Maybe not. If she stays put, can she be detained? According to the EU's Return Directive (2008/115/EC), post-Brexit British citizens who do not, or no longer, have a right to stay would have to be expelled, by force if they did not go voluntarily. To facilitate departure, they could be detained for up to six months, or up to 18 months if there were complications with their removal.

While UK citizenship is currently seen as part of the elite club of the top-quality nationalities scholars predict a drastic fall in value. Dimitry Kochenov speaks of 'one of the most radical losses in the value of a particular nationality in recent history $(. .$.$) a loss of 30 \%$ of UK nationality's value, an overwhelming downgrade to the level of Argentinian and Chilean nationality' (Kochenov 2016a). ${ }^{23}$ This effect is partially due to the fact that entitlements tied to national citizenship are, albeit with many caveats, made exportable, which basically extends the reach of national citizenship across its national borders: There is differential treatment between claims made against host member states and those made against home member states. Claims against host states are subjected to stricter conditions (e.g. Case C-308/14 Commission v United Kingdom; Case C-333/13 Dano) whereas claims against home states to looser conditions (e.g. Case C-359/13 Martens). This has led to the claim that Union citizenship would rather reinforce national citizenship, than the opposite (Strumia 2015; contra Davies 2005).

An agreementless Brexit, some claim, means 'that UK citizens in the EU would have a legal position inferior to Russians and Moroccans (whose countries have non-discrimination agreements with the EU)' (Kochenov 2016b). ${ }^{24}$ For some, 'British expatriates in the EU will be, in effect, the eggs that have to be broken to make the omelets of those British politicians who feel uncomfortable living next to Romanians' (Peers 2014).

The tales of Oliver, Francisca, Ryan, Abigail and the others work as a powerful reminder of the fact that people all around the Union rely on their treaty rights to make life choices. It is not only libraries - pace von Kirchmann - that 'only three words of the legislature can destroy.' Let us see if we are able to give some solace to them. I suggest doing so requires advancing a theoretically informed inquiry. But first let us be clear about why such a take is needed. 


\section{Notes}

1. The reported surge in hate-crimes registered post-Brexit seems to confirm the reading.

2. For a broader impact assessment, see Peers 2016a.

3. See Joint Cases 356/11 and 357/11, O, S EU:C:2012:776, $\mathbb{S}$ 52; Case C-87/12, Ymeraga EU:C:2013:291, $\$ 38$. Also see Case C-86/12, Alokpa EU:C:2013:645.

4. See http://www.migrationobservatory.ox.ac.uk/resources/commentaries/ today-gone-tomorrow-status-eu-citizens-already-living-uk/ (last accessed 12 November 2016).

5. UN DESA Population Division (2015), 'Trends in international migrant stock: the 2015 Revision,' UN. Doc. POP/DB/MIG/Stock/Rev.2015.

6. See Eurostat (2016), 'Population on 1 January by five year age group, sex and citizenship (migr_poplctz)' (http://ec.europa.eu/eurostat/web/populationdemography-migration-projections/population-data/database/).

7. EU Parliament report, Disenfranchisement of EU citizens resident abroad, June 2015, available at http:/ /www.europarl.europa.eu/RegData/etudes/ IDAN/2015/564379/EPRS_IDA(2015)564379_EN.pdf (last accessed 12 November 2016).

8. Non-discrimination on the grounds of nationality, the very principle holding together the legal positions attributed to Union citizens, applies independently of residence on 'Union territory' (C-300/4, Eman and Sevinger, EU:C:2006:545 [2006] ECRI-8055].

9. The Leave campaigned made this claim: http://www.voteleavetakecontrol. org/restoring_public_trust_in_immigration_policy_a_points_based_non_ discriminatory_immigration_system. A 2016 lib-dem bill advocates a 'sunset clause' that would allow EU citizens to continue on the track of acquiring right of permanent residence or indefinite leave to remain for a number of coming years. Indefinite leave offers fewer protections against deportation than permanent residence. In general, a leave is a concession and not a right. The Belgian Cour Constitutionnelle has formulated the point in crystal clear terms: the grant of a residence permit 'constitue une faveur et non un droit' (Cour Constitutionnelle, judgment of 26 September 2013, no. 123, available at http://www.const-court.be/public/f/2013/2013-123f.pdf, at 7).

10. Scholars have also pointed out the risk of 'brain drain' from the UK: Shaw 2016.

11. The fact that naturalising involves loss of Treaty rights is entrenched in the EU citizenship idea. Notice that the history of EU citizenship is strongly marked in this sense: already at the Paris summit 1977 when talk of 'European identity' pushed for the acknowledgement of 'special rights' (i.e. privileges) for nationals of member states in respect of nationals of 
non-member states, the Report presented by the Commission to the Council on 3 July 1975, Commission of EC, Bulletin of the European Communities, Supplement 5/75, COM (75) 321 final, Brussels 2 July 1975, stated at 32: 'in the view of the probable development of the Community this possibility [of encouraging the naturalisation of workers going to other member states] involving a simple exchange of nationality seems less promising than the idea of equality with the nationals of the host State.' On the history of EU citizenship see Maas 2007.

12. According to barrister Colin Yeo, there are tens of thousands of persons in this situation. Watch Migrants' Rights Network, Q\&A on EU migrants rights after Brexit, available at https://www.youtube.com/watch?v= Doi3KYfkbp8\&spfreload=5 (last accessed 30 October 2016). Generally on the situation of Germans in the UK, Mulder 2016.

13. On the 'fabrication of citizens' and its political consequences, see Mindus 2014 , chapter 3 section 6 . On the multiplicity of statuses in British nationality law see Sawyer and Wray 2014.

14. See https://www.theguardian.com/politics/2016/oct/19/hugeincrease-britons-seeking-citizenship-eu-states-brexit-looms (last accessed 30 October 2016).

15. Freedom of movement and residence is not an entitlement strictly linked to Union citizenship: its ratio personae is both over- and under-inclusive. It is not recognised unconditionally to Union citizens (as underscored by Case C-333/13 Dano EU:C:2014:2358) and a number of third country nationals are covered by acquis in relation to freedom of movement. Third country nationals holding a valid residence permit or visa have the right to move freely within the Schengen area for up to three months within a sixmonth period, the rights in relation to taking up residence for a period exceeding three months in another member state is covered by specific legal instruments, depending on their status, and subject to conditions in national legislation (e.g. blue card, intracorporate transfers, long-term residents, researchers, students). See Spaventa 2008; García Andrade 2014, $111 \mathrm{ff}$.

16. Except the 12 member states were provided for by national law. See the seminal comparative work in Shaw 2007.

17. See e.g. Case C-503/09, Lucy Stewart EU:C:2011:500.

18. See e.g. Case C-224/02, Pusa (Opinion of A.G. Jacobs) EU:C:2003:634; Case C-406/04, De Cuyper EU:C:2006:491). For an analysis of these, see Strumia 2013, pp. 441-447.

19. EU Directive on third country national researchers $2005 / 71$ EC, $12 / 10 /$ 2005 OJ L 289, 18.6.2009, 17-29.

20. Data from Department for Work and Pensions: http://tabulation-tool.dwp. gov.uk/100pc/sp/cccountry/cat/ccgor/a_carate_r_cccountry_c_cat_p_ ccgor_claimants_living_abroad_augl5.html (last accessed 30 October 2016). 
21. Directive 2004/114/EC on the conditions of admission of TCN for the purposes of studies, pupil exchange, unremunerated training or voluntary service. See also De Witte 2013.

22. See the Directive 2014/36/EU of the European Parliament and of the Council of 26 February 2014 on the conditions of entry and stay of third-country nationals for the purpose of employment as seasonal workers.

23. Contrarily to Viviane Reding, according to whom 'one should not put a price tag on Union citizenship' (Speech before European Commission 'European citizenship should not be up for sale,' Speech/14/18, 15 January 2014), this is being done: See the newly launched index of the 'value' of nationality quality of nationality index that was developed by Kochenov in collaboration with Henley \& Partners: see https://www.natio nalityindex.com/ (last accessed 30 October 2016). It is being used by governments to see how valuable their citizenship is, by prospective buyers to check the merchandise, and by those making projections on the 'value' of citizenship.

24. The number of applications to the Maltese individual investor program that have been withdrawn after the referendum is telling.

\section{REFERENCES}

Azoulai, L. (2014) 'The (Mis)Construction of the European Individual. Two Essays on Union Citizenship Law', EUI Working Paper LAW 2014/14.

Carrera, S., Guild, E., Chun Luk, N. (2016) 'What Does Brexit Mean for the EU's Area of Freedom, Security and Justice?,' CEPS, July 2016, available at https:// www.ceps.eu/publications/what-does-brexit-mean-eu\%E2\%80\%99s-area-free dom-security-and-justice (last accessed 30 October 2016).

Davies, G. (2005) “Any Place I Hang My Hat" or Residence is the New Nationality', 11 Environmental Law Journal 43.

De Groot, G.R. (2004) 'Towards a European Nationality Law', 8 Electronic Journal of Comparative Law, available at http://www.ejcl.org/83/art83-4. html (last accessed 30 October 2016).

De Witte, F. (2013) 'Who Funds the Mobile Student? Shedding Some Light on the Normative Assumptions Underlying EU Free Movement Law', 50 Common Market Law Review 203.

Douglas-Scott, S. (2015) 'Constitutional Implications of a UK Exit from the EU: Some Questions that Really Must be Asked', U.K. Const. L. Blog, (17th Apr 2015), available at https://ukconstitutionallaw.org/2015/04/17/sionaidhdouglas-scott-constitutional-implications-of-a-uk-exit-from-the-eu-some-ques tions-that-really-must-be-asked/ (last accessed 30 October 2016). 
Douglas-Scott, S. (2016) 'What Happens to Acquired Rights in the Event of Brexit?', U.K. Const. L. Blog (16th May 2016), available at https://ukconsti tutionallaw.org/2016/05/16/sionaidh-douglas-scott-what-happens-toacquired-rights-in-the-event-of-a-brexit/ (last accessed 30 October 2016).

Eleftheriadis, P. (2012) 'Citizenship and Obligation', in J. Dickson, P. Eleftheriadis (eds.) Philosophical Foundations of European Union Law, Oxford: OUP.

Eurostat. (2016) 'Population on 1 January by five year age group, sex and citizenship (migr_poplctz)', available at http://appsso.eurostat.ec.europa.eu/nui/ show.do?dataset=migr_poplctz\&lang=en (last accessed 20 January 2017).

García Andrade, P. (2014) 'Priviledged Third-Country Nationals and Their Right to Free Movement and Residence to and in the EU: Questions of Status and Competence', in E. Guild, C. Gortázar Rotaeche, D. Kostakopoulou (eds.) The Reconceptualization of European Union Citizenship, Leiden: Brill, $111 \mathrm{ff}$.

Kelsen, H. (1945) General Theory of Law and State, Cambridge, MA: Harvard University Press.

Kochenov, D. (2016) [2016a] EU Citizenship and Withdrawals from the Union: How Inevitable is the Radical Downgrading of Rights?, LEQS Paper No. 111/2016, available at http://www.lse.ac.uk/europeanInstitute/LEQS\%20Discussion\% 20Paper\%20Series/LEQSPaper111.pdf (last accessed 30 October 2016).

Kochenov, D. (2016) [2016b] 'Brexit and the Argentinianisation of British Citizenship: Taking Care Not to Overstay Your 90 Days in Rome, Amsterdam or Paris', VerfBlog, 2016/6/24, available at http://verfassungsblog.de/brexitand-the-argentinisation-of-british-citizenship-taking-care-not-to-overstay-your90-days-in-rome-amsterdam-or-paris/ (last accessed 30 October 2016).

Kostakopoulou, D. (2008) The Future Governance of Citizenship, Cambridge: CUP. Maas, W. (2007) Creating European Citizens, Lanham: Rowman \& Littlefield Publishers.

Mindus, P. (2014) Cittadini e no. Forme e funzioni dell'inclusione e dell'esclusione, Florence: Firenze University Press.

Mulder, J. (2016) 'The Personal Implications of the Referendum Results for (German) EU Citizens Living in the UK', German Law Journal - Brexit Supplement, available at https://staticl.squarespace.com/static/56330ad3e4b0733dcc0c8495/t/ 5776e5e6579fb3bc18d93eab/1467409894916/15+PDF_Vol_17_Brexit +_Mulder.pdf (last accessed 30 October 2016).

Peers, S. (2014) 'What Happens to British Expatriates?', Blog entry from 9 May 2014 EU Law Analysis Blog, available at http://eulawanalysis.blog spot.se/2014/05/what-happens-to-british-expatriates-if.html (last accessed 30 October 2016).

Peers, S. (2016) [2016a] 'Migration, Internal Security and the UK's EU Membership', 87 The Political Quarterly 2, 247-253, April-June 2016.

Peers, S. (2016) [2016b] 'Goodbye, Cruel World: Visas for Holidays After Brexit?', Blog entry from 25 April 2016 EU Law Analysis, available at 
http:/ / eulawanalysis.blogspot.se/2016/04/goodbye-cruel-world-visas-forholidays.html (last accessed 30 October 2016).

Sawyer, C., Wray, H. (2014) EUDO Country Report: United Kingdom (revised and updated 2014), available at http://cadmus.eui.eu/bitstream/handle/1814/ 33839/EUDO-CIT_2014_01_UK.pdf (last accessed 30 October 2016).

Shaw, J. (2007) The Transformations of Citizenship in the European Union. Electoral Rights and Restructuration of Political Space, Cambridge: CUP.

Shaw, J. (2016) 'Citizenship, Migration and Free Movement in Brexit Britain', 17 German Law Journal - Brexit Special Supplement, available at https://staticl.squarespace.com/static/56330ad3e4b0733dcc0c8495/ t/577ef48c20099e34c7327fel/1467937934684/19+PDF_Vol_17_ Brexit+_Shaw.2.pdf (last accessed 30 October 2016).

Somek, A. (2011) Engineering Equality. An Essay on European Anti-Discrimination Law, Oxford: OUP.

Spaventa, E. (2008) 'Seeing the Woods Despite the Trees? On the Scope of Union Citizenship and its Constitutional Effects', 45 Common Market Law Review 13.

Strumia, F. (2013) 'Looking for Substance at the Boundaries: European Citizenship and Mutual Recognition of Belonging', 32 Yearbook of European Law 432-459.

Strumia, F. (2015) 'The Asymmetry in the Right to Free Movement of European Union Citizens: The Case of Students', Blog entry from 12 May 2015 EU Law Analysis, available at http://eulawanalysis.blogspot.se/2015/07/the-asymme try-in-right-to-free-movement.html (last accessed 30 October 2016).

Ziegler, R. (2016) 'The Referendum of the UK's EU Membership: No Legal Salve for its Disenfranchised Non-resident Citizens', VerfBlog, 21/06/2016, available at http://verfassungsblog.de/the-referendum-of-the-uks-eu-member ship-no-legal-salve-for-its-disenfranchised-non-resident-citizens/ (last accessed 30 October 2016).

Open Access This chapter is licensed under the terms of the Creative Commons Attribution 4.0 International License (http://creativecommons.org/licenses/ by $/ 4.0 /$ ), which permits use, sharing, adaptation, distribution and reproduction in any medium or format, as long as you give appropriate credit to the original author(s) and the source, provide a link to the Creative Commons license and indicate if changes were made.

The images or other third party material in this chapter are included in the book's Creative Commons license, unless indicated otherwise in a credit line to the material. If material is not included in the book's Creative Commons license and your intended use is not permitted by statutory regulation or exceeds the permitted use, you will need to obtain permission directly from the copyright holder.

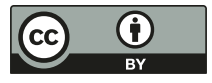

